\title{
THE ALKALINE POST-COLLISIONAL VOLCANISM OF THE CAMPO ALEGRE BASIN, SOUTHERN BRAZIL: PETROGENETIC ASPECTS
}

\section{BRENO LEITÃO WAICHEL ${ }^{1}$, EVANDRO FERNANDES DE LIMA ${ }^{2}$, LAURO VALENTIM STOLL NARDI ${ }^{2}$ AND CARLOS AUGUSTO SOMMER ${ }^{1}$}

\begin{abstract}
The Campo Alegre Formation is composed of volcanic rocks related to the silica saturated alkaline series and represent part of post-collisional Neoproterozoic magmatism (595 $\pm 16 \mathrm{Ma})$ at the end of Brasiliano-Pan-African Orogenic Cycle. Rhyolites are the most abundant lithological types, and occur associated to basalts, trachytes, trachydacites, auto-breccia, pyroclastic flow deposits, dikes and ignimbrites. Two lithological associations, both of alkaline affinity, but with different contents of major and trace elements (e.g. Mg, $\mathrm{P}, \mathrm{Zr}$, Y, $\mathrm{Nb}$, and REE) were distinguished. Their parental basaltic magmas probably represent different fractions of melting from lithpspheric mantle metasomatized by subduction-related fluids during the previous Brasiliano-Pan-African Cycle. The Campo Alegre Basin volcanism is correlated with the Acampamento Velho Formation in the southern portion of this region, in the Sul-rio-grandense Shield.

Keywords:
\end{abstract}

INTRODUCTION Large areas of the Paraná Basin basement, in southern Brazil are occupied by a post-collisional magmatism (Nardi \& Bittencourt 1993), related to the Brasiliano-Pan African Cycle. This magmatic episode has been ascribed to the evolution of the retroarc foreland basins associated with the waning stages of the Brasiliano/ Pan-African Cycle (Gresse et al 1996, Silva 1999). Granites with minor intermediate and basic plutonic rocks, as well as large volcanic plateaus, represent lithological associations related to the calc-alkaline, shoshonitic and silica-saturated alkaline magmatic series. Crust derived granites are also widespread.

The Campo Alegre Basin (CAB) volcanic association represents part of the post-collisional magmatism related to final stages of the Brasiliano/Pan-African cycle in the northeastern of Catarinense Shield (Fig. 1). It consists of a Neoproterozoic volcano-sedimentary sequence (595 $\pm 16 \mathrm{Ma}$, Cordani et al. 1999) lying on older Archean granulite terranes. A large number of metaluminous and peralkaline granites of alkaline affinity in the southern Brazil region present this same age and are probably related to the same parental magmas. The $\mathrm{CAB}$ volcanic association lacks evidence of deformation or metamorphism, and is considered part of an alkaline-silica-saturated post-orogenic magmatism, which includes a large amount of granites. This volcanosedimentary sequence was denominated Guaratubinha Group (Ebert 1971, Daitx and Carvalho 1980) and is constituted by the Bateias, Campo Alegre and Rio Turvo formations. The Bateias Formation represents the lower portions of the sequence and consists of conglomerates and sandstones deposited on the basement. The Rio Turvo Formation occurs in the upper portion of the basin sequence, overlying the Campo Alegre Formation, and encompasses epiclastic and volcanogenic sedimentary deposit.

GEOLOGY OF CAMPO ALEGRE FORMATION The Campo Alegre Formation (CAP) consists predominantly of volcanic rocks, which were grouped in a Lower Effusive Sequence (LES), Intermediary Epiclastic-volcanoclastic Sequence (IEVS) and an Upper Effusive Sequence (UES). The rock classification was based in TAS diagram (Le Bas et al. 1986) (Fig. 2) and $\mathrm{Zr} / \mathrm{TiO}_{2} * 0.0001$ versus $\mathrm{SiO}_{2}$ diagram (Winchester \& Floyd 1977) (Fig. 3). The LES is composed of basalts, in the basal portion and trachytes in the upper portion, the IEVS lies between the effusive volcanic sequences and is made of shales and volcanogenic sedimentary and pyroclastic flow

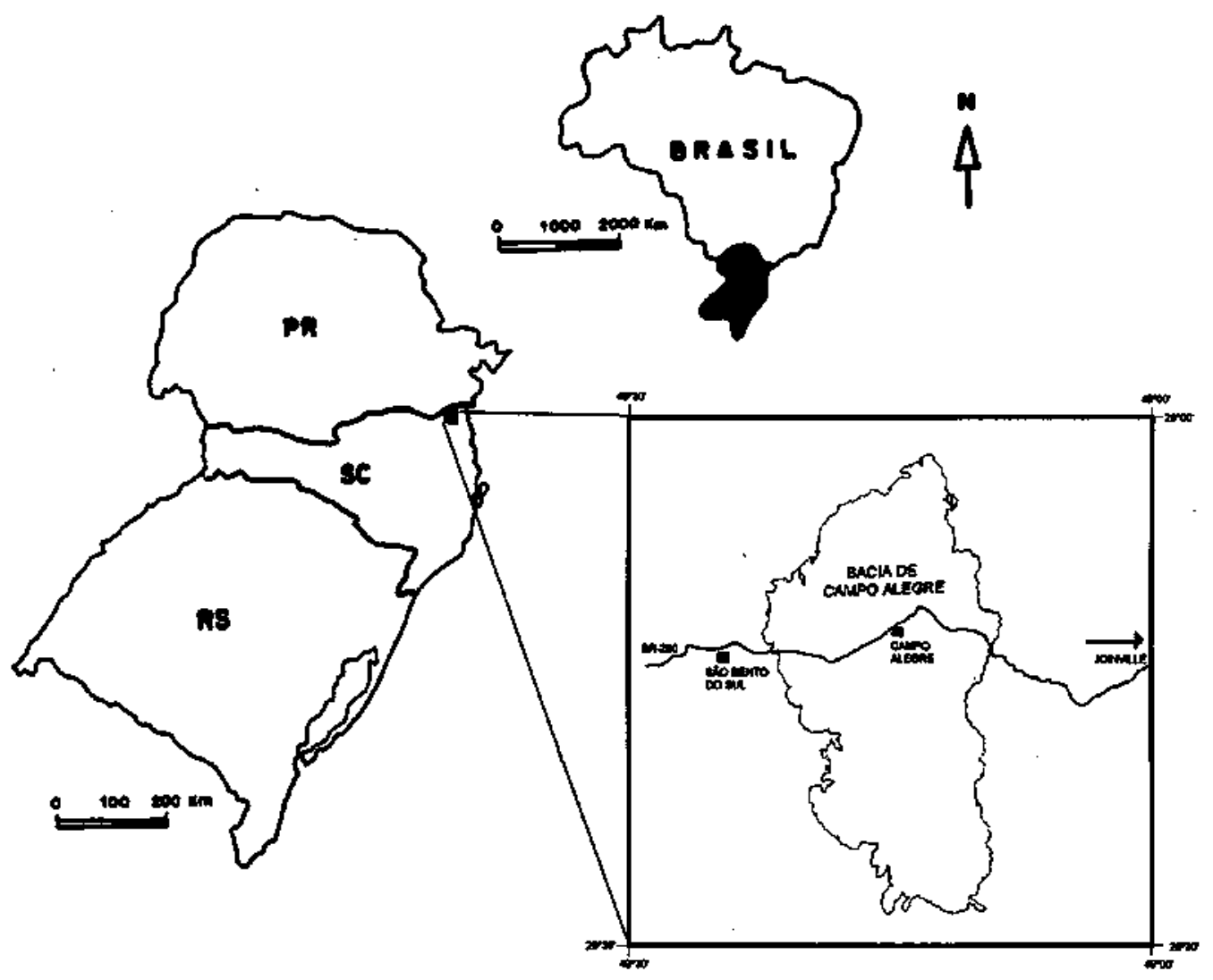

Figure 1 - Localization Map of the Campo Alegre Basin. 
deposits. The UES occurs in the central part of the basin and consists of trachytes and rhyolites Basic volcanic rocks are mostly in the lowest stratigraphic levels, as lava flows or dikes. Basalts have porphyritic texture with phenocrysts of olivine and plagioclase in a matrix made of plagioclase, chlorite, carbonate iron oxides.

The most abundant lithologies are rhyolitic lavas with minor amounts of trachytic and trachydacitic lavas. Felsic rocks show little mineralogical variation. Sanidine and quartz phenocrysts are ubiquitous; arfvedsonite and iron oxides may be present. The matrix, originally glass, was converted to fine-grained quartz-feldspar aggregates. Spherulites and micropoikilitic textures are present in denitrified acid lavas. Autobreccia also occurs and represents nonexplosive fragmentation of flowing lava. The process commonly affects the external surfaces of the lava flows and generates a layer of rigid blocks, plates and spines.

Pyroclastic flow deposits are common as welded high temperature ignimbrites. Volcanogenic sedimentary deposits represent gaps between eruptive periods marked by weathering and erosion.

\section{MAJOR- AND TRACE-ELEMENT GEOCHEMISTRY}

Geochemical studies in the Campo Alegre Formation (CAP) were based on major-, trace- and rare earth (REE) element data, obtained from 26 volcanic whole-rock samples (Table 1). Analytical determinations were performed by Activation Laboratories, Ontario, Canada, through Inductively Coupled Plasma (ICP) analysis for major elements and Inductively Coupled Plasma Mass Spectrometry (ICPMS) for trace elements and REE.

The geochemical characterization of the CAF rocks was based mainly on low mobility elements, due to high Loss on Ignition (LOI) values found mainly in the basic rocks and the large $\mathrm{Na}_{2} \mathrm{O}$ and $\mathrm{K}_{2} \mathrm{O}$ content variations in the trachytic and rhyolitic rocks, probably reflecting loss of alkali elements.

Table 1 - Chemical analyses (major in \% wt; trace and REE elements in ppm) of the $C A F$ : average values.

\begin{tabular}{|c|c|c|c|c|c|c|}
\hline & $\begin{array}{c}\text { EBas } \\
\text { (2) }\end{array}$ & $\begin{array}{l}\text { Whas } \\
\text { (2) }\end{array}$ & $\begin{array}{c}\text { L.ES } \\
\text { (5) }\end{array}$ & $\begin{array}{l}\text { UTS } \\
(7)\end{array}$ & $\begin{array}{c}\text { L-ZrR } \\
\text { (6) }\end{array}$ & $\begin{array}{c}\text { H-ZrR } \\
\text { (A) }\end{array}$ \\
\hline $\mathrm{SiOh}_{2}$ & 46.9 & 49.4 & 67.6 & 663 & 75.0 & 73.3 \\
\hline $\mathrm{Al}_{2} \mathrm{O}_{3}$ & 16.5 & 16.1 & 14.7 & 14.7 & 12.8 & 12.8 \\
\hline $\mathrm{Fe}_{2} \mathrm{O}_{3}$ & 10.8 & 8.6 & 5.1 & 6.8 & 1.4 & 4.2 \\
\hline $\mathrm{MgO}$ & 8.3 & 3.6 & 0.2 & 0.4 & 0.1 & 0.1 \\
\hline $\mathrm{CaO}$ & 7.2 & 8.6 & 0.7 & 0.4 & 0.1 & 0.4 \\
\hline $\mathrm{Na}_{2} \mathrm{O}$ & 3.8 & 3.0 & 4.3 & 3.6 & 2.0 & 3.8 \\
\hline $\mathrm{K}_{2} \mathrm{O}$ & 0.4 & 0.9 & 4.7 & 5.5 & 6.2 & 5.1 \\
\hline $\mathrm{TiO}_{2}$ & 1.5 & 1.4 & 0.7 & 0.7 & 0.1 & 0.3 \\
\hline $\mathrm{P}_{2} \mathrm{O}_{3}$ & 0.2 & 0.6 & 0.3 & 0.1 & 0.03 & 0.04 \\
\hline $\mathrm{Ba}$ & 833 & 850 & 1750 & 724 & 713 & 292 \\
\hline $\mathbf{R b}$ & 13 & 19 & 150 & 90 & 157 & 119 \\
\hline Th & 0.8 & 4.7 & 15.6 & 10.4 & 25.4 & 28.3 \\
\hline Nb & 5 & 20 & 33 & 20 & 15 & 37 \\
\hline $\mathbf{T a}$ & 0.3 & 1.1 & 1.8 & 1 & 2.6 & 2.6 \\
\hline $\mathbf{S r}$ & 698 & 787 & 267 & 73 & 55 & 33 \\
\hline $\mathbf{Z r}$ & 116 & 272 & 476 & 674 & 148 & 1200 \\
\hline Hf & 3 & 6.2 & 12.6 & 14.4 & 6.2 & 25 \\
\hline$Y$ & 27 & 37 & 72 & 54 & 37 & 118 \\
\hline $\mathbf{L a}$ & 11.6 & 64.2 & 92.7 & 82.9 & 74.7 & 148 \\
\hline $\mathrm{Ce}$ & 26 & 123 & 208 & 136 & 111 & 271 \\
\hline $\mathbf{P r}$ & 3.3 & 12.9 & 20.3 & 17.6 & 3.9 & 30 \\
\hline $\mathbf{N d}$ & 16.4 & 51.7 & 79 & 70.1 & 46.2 & 119.2 \\
\hline $\mathrm{Sm}$ & 4.1 & 9.2 & 15.6 & 12.9 & 8.7 & 23.5 \\
\hline Eu & 1.6 & 2.5 & 2.7 & 2.2 & $0.5 t$ & 1.2 \\
\hline Gd & 4.8 & 8.7 & 15.2 & 12 & 8 & 22.9 \\
\hline $\mathrm{Tb}$ & 0.8 & 1.2 & 2.3 & $1.8^{\circ}$ & 1.2 & 3.6 \\
\hline Dy & 4,4 & 6.1 & 12.5 & 9.5 & 6.4 & 20.4 \\
\hline Ho & 0.9 & 1.1 & 2.4 & 1.9 & 1.2 & 4 \\
\hline $\mathrm{Er}$ & 2.6 & 3.3 & 7.1 & 5.7 & 3.8 & 12 \\
\hline$T_{m}$ & 0.3 & 0.4 & 1 & 0.8 & 0.5 & 1.8 \\
\hline $\mathbf{Y b}$ & 2.3 & 2.8 & 6.4 & 5.3 & 3.5 & 11.3 \\
\hline Lu & 0.3 & 0.4 & 0.9 & 0.8 & 0.5 & 1.8 \\
\hline $\mathrm{Nb} / \mathrm{Z}$ & 0.04 & 0.08 & 0.06 & 0.03 & 0.1 & 0.03 \\
\hline $\mathrm{Ce} / \boldsymbol{Z}$ & 0.22 & 0.45 & 0.44 & 0.22 & 0.75 & 0.29 \\
\hline $\mathrm{La} / \mathrm{Zr}$ & 0.1 & 0.23 & 0.19 & 0.12 & 0.5 & 0.15 \\
\hline $\mathbf{R} \mathbf{b} / \mathbf{Z}$ & 0.11 & 0.07 & 0.34 & 0.15 & 1.08 & 0.12 \\
\hline
\end{tabular}

The bimodal distribution of the CAF lithologies is indicated by the compositional gap in the 53 to $63 \%$ of $\mathrm{SiO}_{2}$ interval.

Two different basic magmas were identified in the CAF: Eastern Basalts (EBas) and Western Basalts (WBas). This geographic separation is also supported by geochemical characteristics such as the abundance of $\mathrm{MgO}, \mathrm{P}_{2} \mathrm{O}_{5}, \mathrm{Zr}, \mathrm{Nb}, \mathrm{Y}$, and REE contents and $\mathrm{La} / \mathrm{Yb}$ ratios. EBas represent the least differentiated basic magmas, with $8 \%$ wt. of $\mathrm{MgO}$ and low $\mathrm{Cr}$ and $\mathrm{Ni}$ values. These features, including the lack of negative $\mathrm{Eu}$ anomaly, are coherent with a differentiated character caused by olivine \pm pyroxene fractionation. $\mathrm{Nb}$ negative anomaly relative to LREE suggests a lithospheric mantle source modified during previous subduction (Fig. 4). The EBas show a slight LREE enrichment relative to heavy REE (HREE), illustrated by subhorizontal chondrite normalized REE patterns with $\mathrm{La} / \mathrm{Yb}_{\mathrm{N}}$ ratios varying around $3-4$, similar to those of the calc-alkaline ana mildly alkaline basalts (Fig. 4). The Ba positive anomaly indicates the interaction of mantle sources or of parental magmas with continental crust materials, and the high $\mathrm{Ba} / \mathrm{La}$ ratios suggests the presence of $\mathrm{Ba}-$ enriched fluids in the source, related to subduction zones (Wilson 1989). The EBas trace elements normalized against MORE values show patterns similar to those of calc-alkaline basalts, except for the lower values of $\mathrm{Rb}$ and $\mathrm{Th}$ and the higher Ba contents (Fig. 5).

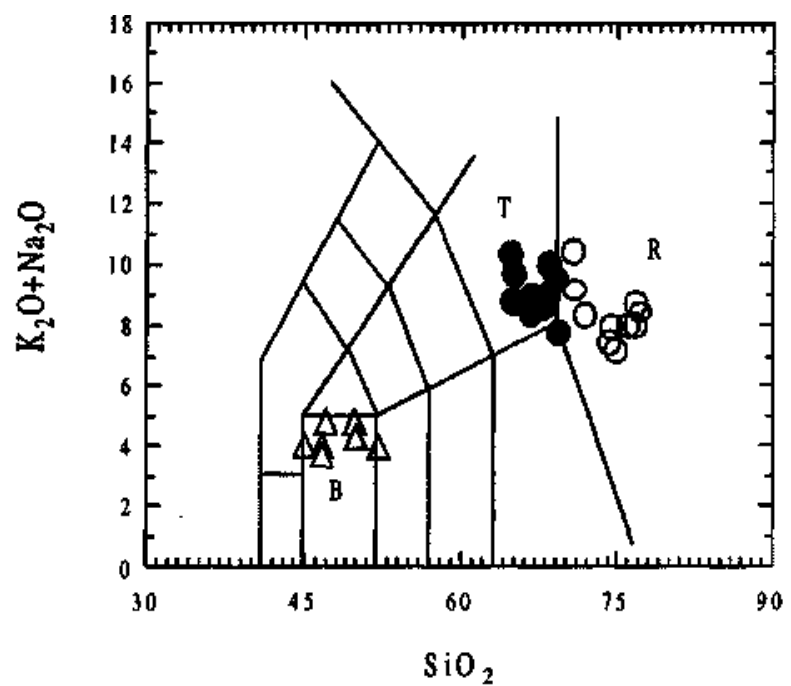

Figure 2 - FCA samples plotted in TAS diagram (Le Bas et al. 1986). Legend: $0=$ trachytic rocks; $-=$ thyolitic rocks; $\Delta=$ basic rocks.

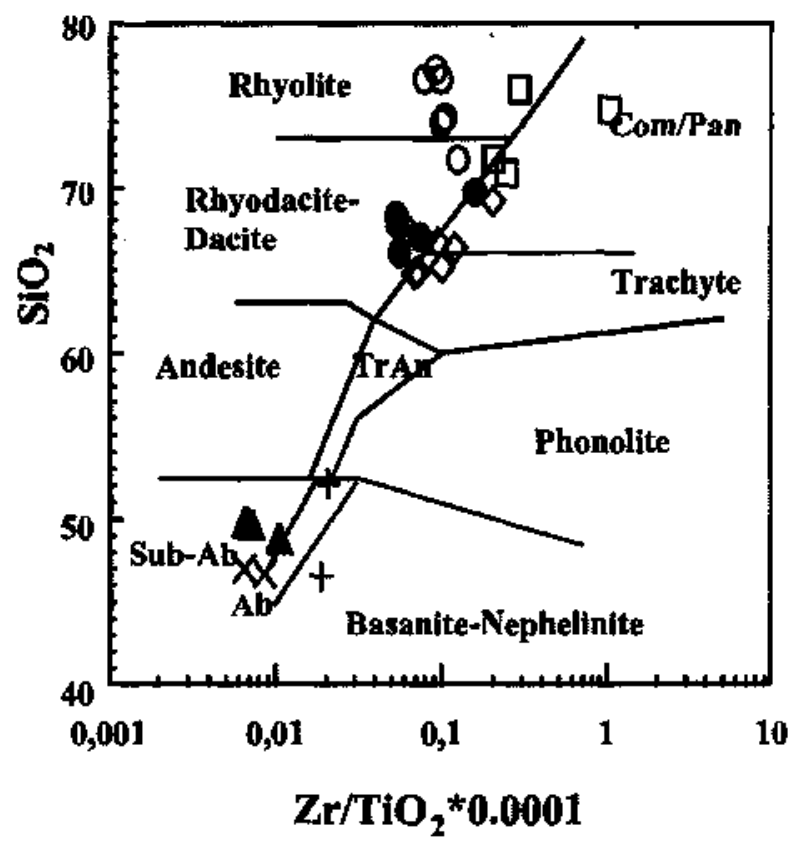

Figure 3 - FCA samples plotted in the $\mathrm{SiO}_{2} \times \mathrm{ZrTiO}$ diagram (c.f. Winchester \& Floyd (1977). Legend: $\mathrm{X}=$ EBas; $+=$ WBas; $\boldsymbol{A}=$ diabases; $O=$ LES trachytes; $\downarrow=$ UES trachytes; $\theta=H-Z$ r thyoliles; $?=L-Z r$ riyolites. 

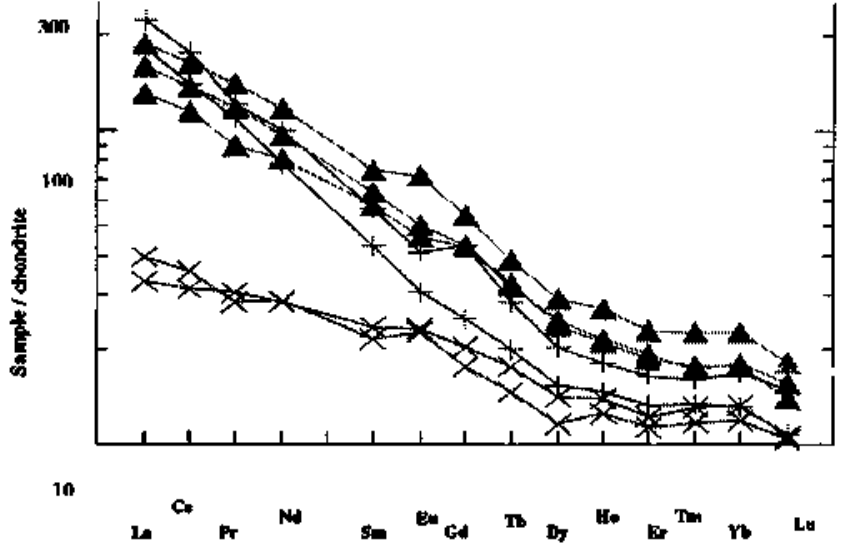

Figure 4 - Basic rocks $R E E$ variation diagram. Values are patterned from Haskin chondrite (Haskin et al. I968). Legend: $X=$ EBas; $+=$ WBas; $\Delta=$ diabases.

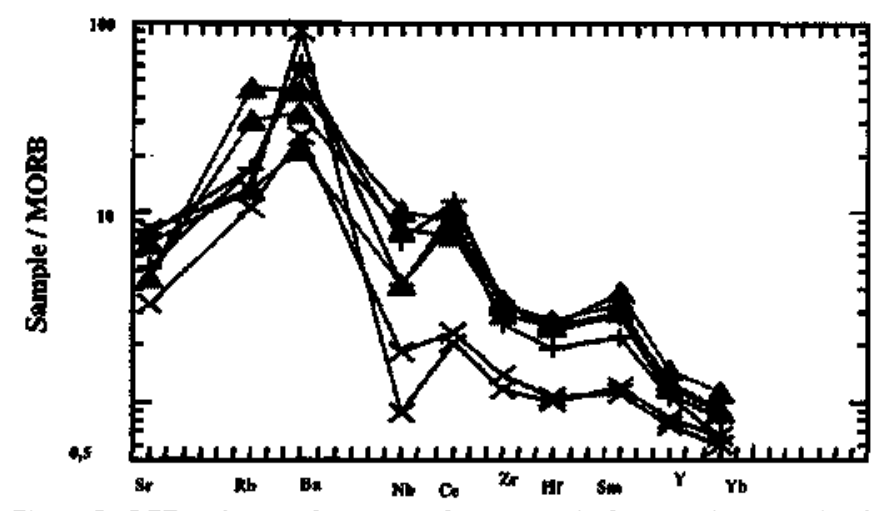

Figure 5 - REE and trace elements spidergram of the basic rocts, normalized from MORB. Legend: $X=$ EBas; $+=$ WBas; $\boldsymbol{\nabla}=$ colc-alkaline basalis; $=$ within plate alkaline basals (data from Peare 1982).
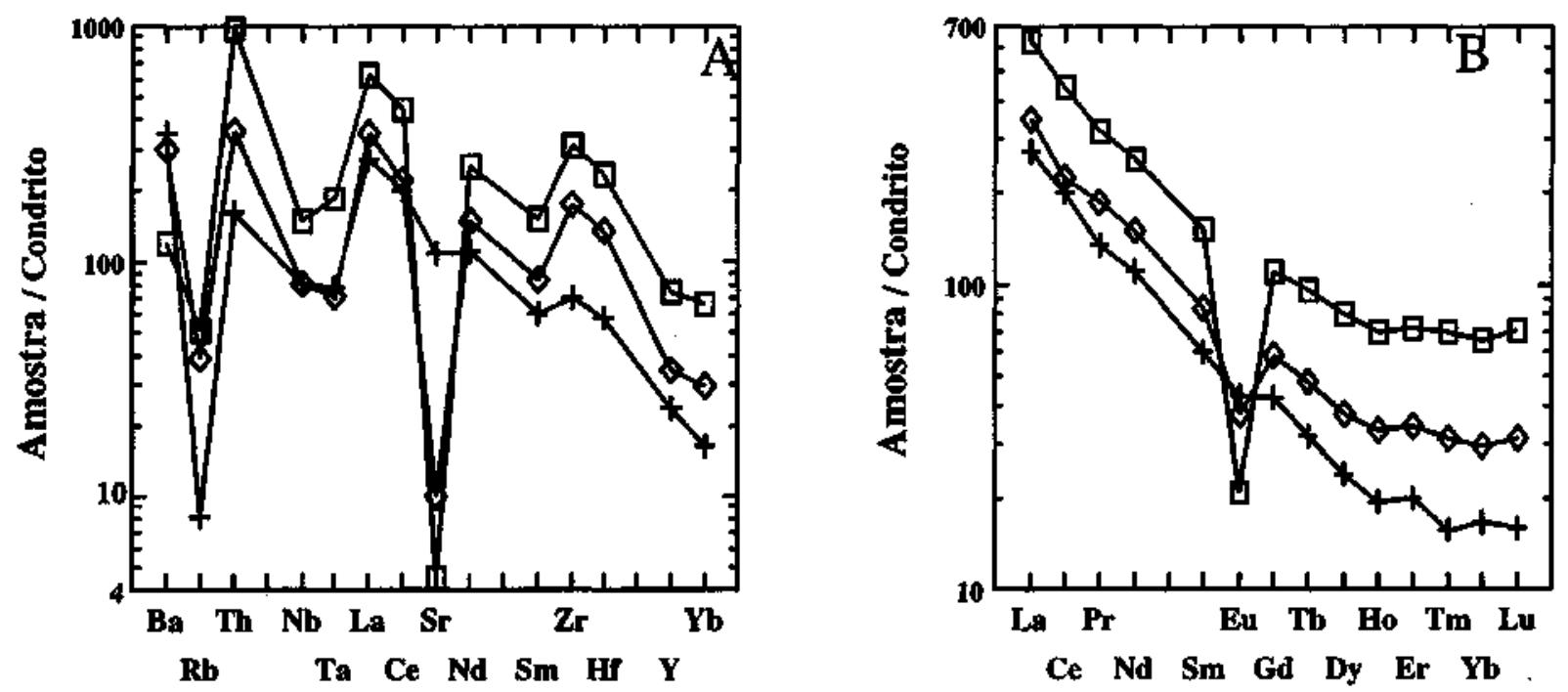

Figure 6 - WBas basalts, LES trachytes and H-Zr rhyolites trace and REE elements spidergram (A) and REE variation diagram (B). Values are patterned from Haskin chondrite (Haskin et al. 1968). Legend: += WBas; $\downarrow=$ UES trachytes; $\theta=$ H-Zr rhyolites.

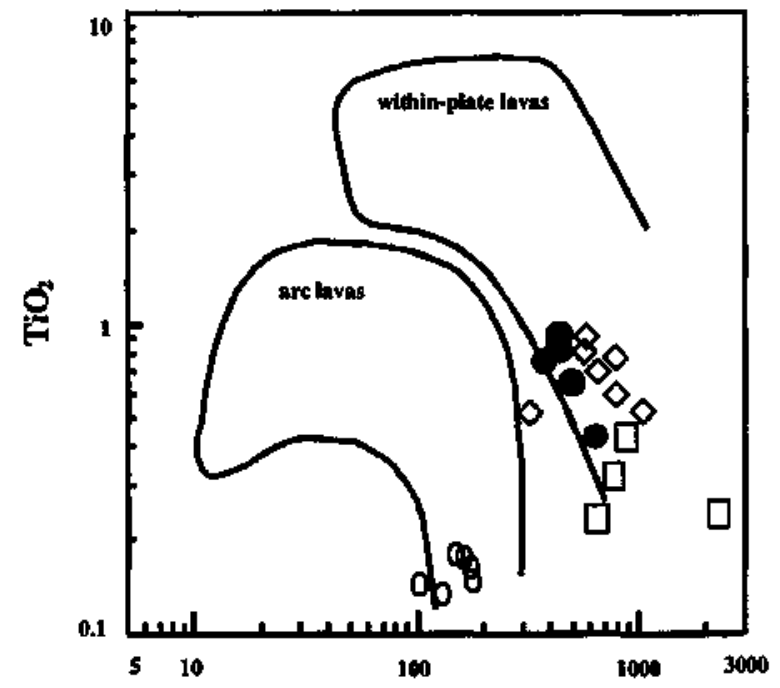

$\mathbf{Z r}$

Figure 7 - FCA trachytic and rhyolitic rocks plotted in the $\mathrm{Zr}$ versus $\mathrm{TiO}$, diagram (Pearce 1980). Legend: ? = LES trachytes; $\downarrow=$ UES trachytes; $0=$ $H$-Zr riyolites; $=L-Z$ r rhyolites.

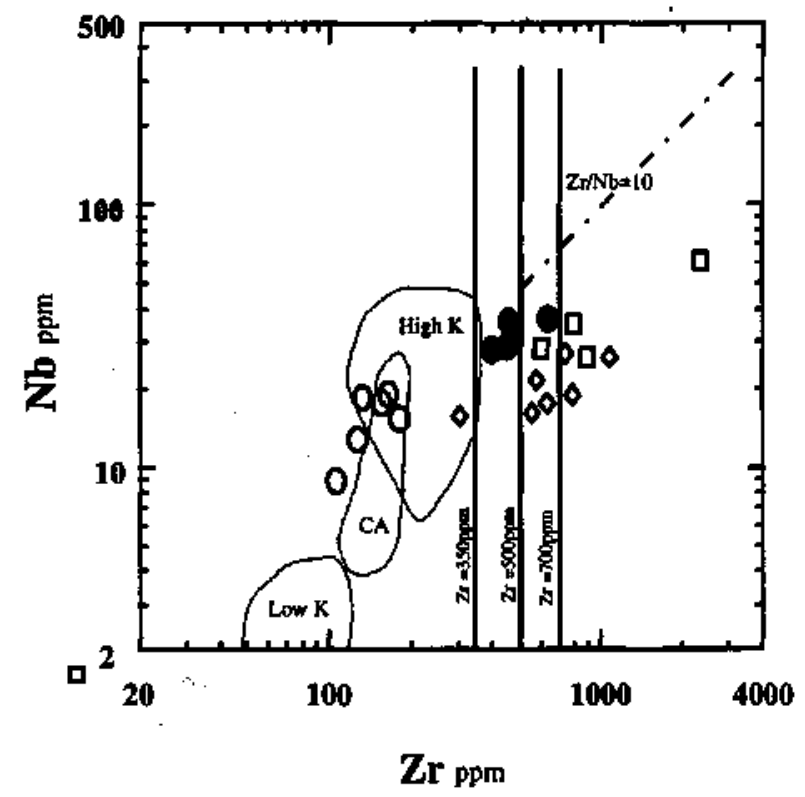

Figure 8-FCA trachyric and rhyolitic rocks plotted in the $Z$ r versus $N b$ diagram (c.f. Leat et al. 1986). Legend: Baixo $K=$ low $K$ calc-alkaline rocks: $C A=$ calc-alkaline rocks; Alto $K=$ high $K$ calc-alkaline rock; ? = LES irachyles; $\downarrow=$ UES trachytes; $\theta=H-Z r$ ipolites; $O=L-Z r$ rbolites. 
The WBas represent fractionated melts with low $\mathrm{MgO}, \mathrm{Cr}, \mathrm{Ni}$, anc $\mathrm{Ti}\left(\mathrm{X}\right.$ and high $\mathrm{P}_{2} \mathrm{O}_{5}, \mathrm{Zr}, \mathrm{Nb}, \mathrm{Y}$ contents. The high $\mathrm{Zr}$ values and the REE pattern suggest the alkaline character of these rocks. Normalizec MORB patterns of trace elements show characteristics similar tc within plate alkaline basalts, except for the lower Nb values (Fig 4) which suggest a mantle source modified by metasomatism associated to subduction (Wilson 1989). When compared to EBas, WBas show REE enrichment and higher $\mathrm{La} / \mathrm{Yb} \mathrm{b}_{\mathrm{N}}$ ratio with values close to 16 to IT (Fig 4). The occurrence of transitional (EBas) and alkaline basalts (WBas) is usual in continental rifts and in post-collisional settings, the chemical differences of their magmas is related to different partial mell degrees in the asthenospheric or lithospheric mantle (Baker et al. 1977, Wilson 1989).

The CAF trachytic rocks show major- and trace element contents similar to continental rift trachytes, except for the lower $\mathrm{Nb}$ values, which are suggestive of post-collisional settings.

The Lower Effusive Sequence (LES) trachytic rocks have higher $\mathrm{Ba}$ (1725-2230), Rb (135-168 ppm), Nb (30-37) and $\mathrm{Sr}$ (224-334 $\mathrm{ppm})$ contents and lower $\mathrm{Zr}$ values (401-470 ppm) when compared to Upper Effusive Sequence (UES). The chondrite normalized REE pattern of LES, show a high LREE / HREE ratio and negative Eu anomalies (Fig 6a).

The UES trachytic rocks have higher $\mathrm{Zr}$ values (557-1045 ppm) and lower $\mathrm{Ba}$ (147-982 ppm), Rb (83-116 ppm), $\mathrm{Nb}$ (15-29 ppm) and $\mathrm{Sr}(23-78 \mathrm{ppm})$ contents. The chondrite normalized REE patterns of the UES show relatively high LREE / HREE ratio. There is one group of UES rocks with negative Eu anomalies (Fig $7 \mathrm{~B}$ ). In the $\mathrm{Zr} \times \mathrm{TiO}_{2}$ diagram (Pearce 1980), the CAF trachytic rocks are situated in the within plate field (Fig. 7). Leat et al. (1986) proposed the utilization of $\mathrm{Zr}$ values and $\mathrm{Zr} \times \mathrm{Nb}$ diagram for the geochemical and tectonic setting characterization of acid rocks. In this diagram, the LES trachytes are situated close to the boundary between alkaline and sub-alkaline fields. The UES trachytes are plotted in the field of peralkaline volcanic rocks related to subduction due to their high $\mathrm{Zr}$ values and $\mathrm{Zr} / \mathrm{Nb}$ ratios (Fig. 8).

Two groups of rhyolitic rocks were recognized based upon the $\mathrm{Zr}$ values: low $Z r$ rhyolites, with values ranging between 107 to $182 \mathrm{ppm}$, and high $\mathrm{Zr}$ rhyolites, with contents ranging between 650 to $2500 \mathrm{ppm}$. The low $\mathrm{Zr}$ rhyolites show lower $\mathrm{Zr}$ (107-182 ppm), Nb (9-19 ppm), Y (33-42 ppm) and $\mathrm{Ga}(16-22 \mathrm{ppm})$ values and higher $\mathrm{Ba}(609-923 \mathrm{ppm})$ and $\mathrm{Sr}(30-60 \mathrm{ppm})$ contents, when compared to high $\mathrm{Zr}$ rhyolites. These chemical characteristics are similar to those of calc-alkaline rhyolitic rocks (Lapierre et al. 1997) or to those of metaluminous rocks of alkaline silica saturated series. In the $\mathrm{Zr} \times \mathrm{TiO} 2$ (Fig. 7) diagram, the low $\mathrm{Zr}$ rhyolites are located in the island-arc lava field and in the $\mathrm{Zr} \mathrm{x} \mathrm{Nb}$ (Fig. 8) diagram they are situated in the calc-alkaline and high-K calc-alkaline fields.

The high-Zr rhyolites have higher trace-element contents: $\mathrm{Zr}$ (650$2500 \mathrm{ppm}), \mathrm{Nb}(24-67 \mathrm{ppm}), \mathrm{Y}(66-255 \mathrm{ppm})$ and $\mathrm{Ga}(25-29 \mathrm{ppm})$, which are characteristic of alkaline rocks (Pearce et al. 1984, Whalen et al. 1987). The very high contents of $\mathrm{Zr}$ suggest the original peralkaline character of these liquids. Low $\mathrm{Ba}$ (131-134 ppm) and $\mathrm{Sr}$ $(15-25 \mathrm{ppm})$ values are suggestive too of the alkaline affinity of these rhyolites (Ewart 1979). When plotted in the $\mathrm{SiO}_{2}$ versus $\mathrm{Zr} / \mathrm{TiO}_{2} \mathrm{x}$ 0,0001 diagram (Winchester \& Floyd 1977), the high-Zr rhyolites are situated in the comendite-pantelerite field (Fig. 2). In the $\mathrm{Zr}$ versus TiO2 diagram (Pearce 1980), these rocks are located in the withinplate field (Fig. 8).In the $\mathrm{Zr} \times \mathrm{Nb}$ diagram (Leat et al. 1986) the high $\mathrm{Zr}$ rhyolites are plotted in the peralkaline volcanic rocks related to subduction field, due to their high $\mathrm{Zr}$ values and $\mathrm{Zr} / \mathrm{Nb}$ ratios.

CONCLUSIONS The geochemical data of volcanic rocks from Campo Alegre Formation indicated the occurrence of two magmatic associations composed of basalts-trachytes-rhyolites, with typical chemical features.In the LES there are two kinds of basalts: the EBas, located in the eastern portion of the basin, are transitional basalts $(\mathrm{Zr}$ $=115 \mathrm{ppm}$ in average; $\mathrm{La} / \mathrm{Yb}_{\mathrm{N}}=4$ ratio), which may be related to calcalkaline or mildly alkaline magmatic series. The association with probably cogenetic trachytes indicates their alkaline affinity. The WBas, situated in the western portion of the basin, are related to the alkaline silica saturated series $\left(\mathrm{Zr}=270 \mathrm{ppm}\right.$ in average and $\mathrm{La} / \mathrm{Yb}_{\mathrm{N}}$ ratio $=17$ ratio). The chemical differences between these basic magmas are ascribed to extractions of different fractions of melt from mantle source. Characteristics such as $\mathrm{Nb}$ negative anomalies, fractionation of REE and LILE enrichment, suggest that these basalts have their source associated to lithospheric mantle modified by subduction.

Trachytic rocks occur in the LES and UES and have different stratigraphic and chemical characteristics. The LES trachytes represent originally metaluminous liquids of mildly alkaline affinity $(\mathrm{Zr}=480$ ppm in average), while the UES trachytes can be considered typically alkaline $(\mathrm{Zr}=680 \mathrm{ppm}$ in average $)$.

Two groups of rhyolitic rocks were distinguished based on $\mathrm{Zr}$ contents. The high $\mathrm{Zr}$ rhyolites show high contents of $\mathrm{Zr}, \mathrm{Nb}, \mathrm{Y}$ and low of $\mathrm{Sr}$ and $\mathrm{Ba}$ and an originally peralkaline character, also suggested by REE patterns. Low $\mathrm{Zr}$ rhyolites have low $\mathrm{Zr}, \mathrm{Nb}, \mathrm{Y}$ and high $\mathrm{Ba}$ and $\mathrm{Sr}$ values, similar to those of calc-alkaline rhyolitic magmas and metaluminous granitic magmas of the post-collisional alkaline associations.

The CAP volcanic rocks belong to a magmatic association of mildly alkaline affinity probably originated from a lithospheric mantle modified by fluids related with the previous Brasiliano subduction event. This volcanic association is comparable to the Taquarembd Plateau volcanism (Wildner et al. 1999), and both represent part of the last manifestations of magmatism in the Brasiliano Pan-African Cycle in southern Brazil.

Acknowledgements This research was financially supported by PRONEX-UFRGS and CNPq 520036/96.4. To two anonymous referees of RBG for their critical review of the manuscript.

\section{References}

Baker B.H., Goles G.G., Leeman W.P., Lindstrom M.M. 1977. Geochemistry and petrogenesis of a basalt-benmoreite-trachyte suite from the southern part of the Gregory Rift, Kenya. Contributions to Mineralogy and Petrology, 64:303-332.

Bitencourt M.F. \& Nardi L.S.V. 1993. Late- to post-collisional Brasiliano Magmatism in southernmost Brazil. Anais da Academia. B.brasileira de.. Ciências.., 65:3-16.

Gordani U.G., Basel M.A.S., Siga Jr. O., Nutman A.. 1999. Idades U-Pb (SHRIMP) de rochas vulcânicas das Bacias de Campo Alegre, Itajaí e Castro (SC e PR). Resumes. rochas vulcânicas das Bacias de Campo Alegre, Itajaí

Daitx E.C. \& Caevalho M.A.S. 1980. Projeto geoquímica na area de Guaratubinha-Pien, Brasil. São Paulo, DNPM/CPRM, 184p.

Ebert H. 1971. 0 Grupo Guaratubinha na none do estado de Santa Catarina. In: Congresso Brasileiro de Geologia, 25, S§o Paulo, 1971. Anais... Sao Paulo, SBG, v.l, p.147165 .

EwartT A. 1979. A review of the mineralogy and chemistry of Tertiary-Recent dacitic, latitic, rhyolitic and related salic volcanic rocks. In: F. Baker (ed.), Trondhjemites, dacites and related rocks, The Hague, Elsevier, p. 113-121.

Gressep P., Chemale Jr. F., Silva L.C. da, Walraven F, Hartmann L.A. 19\%. Late- to postorogenic basins of the Pan-African/Brasiliano collision orogen in southern Africa and orogenic basins of the Pan-African/Brasilar Brazil. Basin Res. 8:157-171.

Haskin L.A, Haskin M.A, Frey F.A, Wildeman T.R. 1968. Relative and absolute terrestrial abundances of the rare earths. In: Archeans L.H.(Ed) Origin and distribution of the abundances of the rare earths. In: Archeans
elements. Oxford, Pergamom, p. 889-912.

Lapierre H, Jahn B.M, Charles J, Yu Y.W. 1997. Mesozoic Arc Magmatism an continental olivine tholeiites in Zhejiang Province and their relationship with the tectonic activity in Southeastern China. Tectonophysics, 274:321-338.

Le Bas M.J., Le Maitre R.W., Streckeisen A., Zanettin B. 1986. A classification of volcanic rocks based on the total alcalis-silica diagram. Journal of Petrology, 27:745-750
Leat P.T, Jackson S.E, Thorpe R.S, Stillman C.J. 1986. Geochemistry of bimodal basaltsubalkaline/perakaline rhyolite provinces within the Southern British Caledonides. Journal of the Geological Society of London, 143:259-273.

Pearce J.A. 1980. Geochimical evidence for the genesis and eruptive setting of lavas from the tethyan ophiolites. Proceedings of the Intern. Ophiolite Simp., Nicosia. Cyprus, p. $261-272$.

Pearce J.A.. Harris N.B.W, Tmole A.G. 1984. Trace element discrimination diagmams for the tectonic interpretation of rocks. Journal of Petrology, 25:956-983.

Silva L.C. da 1999 . Geocronologia U-Pb SHRIMP e Sm-Nd na Provincia Mantiqueira Meridional, no Cinturão Saldania (África do Sul) e a evolufao do Ciclo Brasiliano/ Pan-Africano. Tese de Doutorado. UFRGS. Porto Alegre. 243 p.

Whalen J.B, Currie K.L, Chappell B.W. 1987. A-type granites: Geochimical characteristics, discrimination and petrogenesis. Contr. Mineralogy and Petrology, 87:319-327.

Wildner W. \& Nardi L.V.S. 1999. Post-collisional alkaline magmatism on the Taquarembó Plateau: a well-preserved neoproterozoic-cambrian plutono-vulcanic association in southern Brazil. International Geology Review, 41:1082:1098.

Wilson M.1989. Igneous Petrogenesis. Londres: Unwin Hyman. 466 p.

Winchester J.A. \& Floyd P. A. 1977. Geochemical discrimination of different magma series and their differentiation products using immobile elements. Chemical. Geology, 20:325-343. 